\title{
PENGARUH PENGGUNAAN MEDIA CHROMEBOOK TERHADAP MOTIVASI BELAJAR SISWA
}

\begin{abstract}
Technology always develop all the time, schools need to follow technological

Oleh:

Agus Supriadi ${ }^{1}$ \&

Abdul Muis ${ }^{2}$

Email:

1.agusbelahana@gmail.com ²mu082301583008@gmail.com

Universitas Ibrahimy, Situbondo

developments in terms of the facilities and infrastructure used, including learning media. The method used in this study is a quantitative research. The data analysis technique using descriptive statistical and product moment correlation analysis. To test the bypothesis in this research, using SPSS version 16.0 program. While the data collection, used questionnaires, observations, interviews, and documentation. The result finding of this research that the use of learning media chromebook for students is good category. Meanwhile, for students' learning motivation when using chromebook learning media is the sufficient category. While the calculation in the correlation table on SPSS where the correlation coefficient is 0,543 with signification 0,000. Because the signification $<0,05$, then $\mathrm{Ho}$ is rejected and Ha is accepted, $r$ bitung $>r$ tabel $0,543>0,254$. The conclution, there is a very strong influence on the chromebook learning media implementation on the motivation of class VII students at SMP Negeri 1 Asembagus.
\end{abstract}

Keywords: Chromebook Learning Media, Learning Motivation

\section{PENDAHULUAN}

\section{Konteks Penelitian}

Pendidikan adalah kegiatan yang dijalankan dengan sengaja, teratur, dan berencana dengan maksud mengubah atau mengembangkan perilaku yang diinginkan. Sekolah sebagai lembaga formal merupakan sarana dalam rangka pencapaian tujuan pendidikan tersebut. Melalui sekolah, siswa belajar macam hal. ${ }^{1}$

Sebagaimana UU RI no 20 tahun 2003 tentang SISDIKNAS bahwa pendidikan nasional berfungsi untuk membentuk watak serta peradaban bangsa yang bermartabat dalam rangka mencerdaskan kehidupan bangsa. ${ }^{2}$ Sejalan dengan peningkatan kualitas sumber daya manusia

1 U. Saefullah, Psikologi Perkembangan dan Pendidikan (Bandung: CV Pustaka Setia, 2012), 165.

2 Undang Undang RI Nomor 20 Tahun 2003 Tentang SISDIKNAS dan Peraturan RI Tahun 2013 Tentang Dasar, Fungsi, dan Tujuan, (Bandung: Citra Umbara, 2014), 6. terutama menghadapi abad ke-21 yang ditandai oleh adanya globalisasi dan persaingan ketat, yakni persaingan dengan negara lain.

Untuk bersaing dengan negara lain, pelaksanaan pembelajaran perlu dirancang dan diformat dengan sebaik-baiknya dan kualitas pendidikan harus ditingkatkan. Kehadiran teknologi dalam pembelajaran merupakan tantangan tersendiri bagi dunia pendidikan, khususnya teknologi pembelajaran. Tuntutan dalam menjawab globalisasi pendidikan telah hadir didepan mata. Berbagai perangkat keras (hardware) beserta koneksinya dapat menghantarkan peserta didik secara cepat dan akurat apabila dimanfaaatkan secara benar dan tepat. $^{3}$

3 Sutrisno, Pengantar Pembelajaran Inovatif Berbasis Teknologi Informasi dan Komunikasi (TIK), (Jakarta: Gaung Persada, 2011), 30. 
Pemanfaatan teknologi yang benar dan tepat dapat memperkaya suasana pembelajaran. Pembelajaran berbasis teknologi dapat menyusun pola interaktif yang dapat meningkatkan daya tangkap siswa. Pembelajaran berbasis teknologi merupakan ranah baru yang berkembang dengan pesat dalam teknologi pembelajaran.

Kemajuan dan peranan teknologi dalam pendidikan sudah sedemikian menonjol. Sehingga penggunaan alat-alat, perlengkapan pendidikan, dan pengajaran disekolah mulai disesuaikan dengan kemajuan penggunaan alat-alat bantu mengajar serta perlengkapan sekolah lainnya yang disesuaikan dengan perkembangan teknologi, sehingga pembelajaran menjadi lebih menyenangkan. Revolusi ilmu pengetahuan dan teknologi, perubahan masyarakat, pemahaman cara belajar anak, kemajuan media komunikasi dan informasi memberi arti tersendiri bagi kegiatan pendidikan. Tantangan tersebut menjadi dasar pentingnya pendekatan teknologis dalam pengelolaan pendidikan dan pembelajaran. ${ }^{4}$

Selain itu, media pembelajaran mampu membangkitkan rangsangan pada indera penglihatan, pendengaran, perabaan, dan penciuman siswa. Guru menggunakan sebagai perantara dalam proses pembelajaran agar siswa memahami materi pembelajaran agar lebih efektif dan efisien. Untuk menjamin terjadinya pemanfaatan media pemebelajaran yang optimal, perancangan pembelajaran berbantuan teknologi haruslah secara cermat memperhitungkan terlebih dahulu bagaimana proses pembelajaran yang terjadi pada setiap individu.

Dengan danya media pembelajaran berbasis teknologi, pembelajaran dapat memperkaya menyenangkan dan dapat menyusun pola interaktif yang dapat meningkatkan retensi belajar bagi peserta didik. Dengan adanya media tersebut, peserta didik menemukan suasana baru. Chromebook merupakan salah satu media pembelajaran yang berbasis teknologi. Chromebook merupakan hasil perkembangan dari komputer dan didesaign untuk mempermudah pembelajaran.

Di SMP negeri 1 Asembagus media chromebook merupakan media pembelajaran model baru. Chromebook diberikan oleh pemerintah

4 Munadi Yudi, Media Pembelajaran Sebagai Pendekatan Beru, (Jakarta: GP Press Group, 2013), sebanyak 300 unit dan hanya digunakan untuk kelas VII karena merupakan jenjang awal. Chromebook baru digunakan awal semester 2, dan untuk saat ini siswa masih jarang yang mahir dalam menggunakan chromebook dikarenakan chromebook media baru dan jarang sekali sekolah yang menggunakannya.. Dalam menggunakan chromebook, para guru diwajibkan mengikuti pelatihan penggunaan chromebook selama 4 hari. Sebelum para guru mengikuti pelatihan, ada 4 guru yang ikut pelatihan penggunaaan chromebook yang dibimbing langsung oleh pihak google. Pelatihan guru di SMP Negeri 1 Asembagus sendiri, dibimbing oleh guru yang mengikuti pelatihan bersama pihak google. Pelatihan tersebut dilakukan agar ketika menggunakan chromebook, para guru tidak kebingungan ketika salah satu siswa ada yang belum faham saat menggunakan chromebook, karena penggunaan chromebook dilakukan secara online. Untuk saat ini chromebook hanya digunakan untuk kelas VII A,B,C dan D karena merupakan kelas favorit, dan untuk saat ini tidak semua mata pelajaran menggunakan cbromebook termasuk mata pelajaran PAI.

Berdasarkan pernyataan di atas, maka dianggap penting untuk melakukan penelitian dengan judul Pengaruh Penggunaan Media Chromebook Terhadap Motivasi Belajar Siswa Kelas VII di SMP Negeri 1 Asembagus Tahun Pelajaran 2018-2019.

\section{Perumusan Masalah}

Berdasarkan latar belakang, maka Perumusan masalah dalam penelitian ini sebagai berikut :

1. Bagaimana penggunaan media chrommebok chromebook pada siswa di SMP Negeri 1 Asembagus?

2. Bagiamana motivisi siswa di SMP Negeri 1 Asembagus ketika belajar menggunakan media chromebook?

3. Apakah ada pengaruh penggunaan penggunaa chromebook pada siswa di SMP Negeri 1 Asembagus?
(J) 


\section{Tujuan Penelitian}

Berdasarkan perumusan masalah diatas tujuan penelitian sebagai berikut :

1. Untuk mendiskripsikan penggunaan media chrommebok chromebook pada siswa di SMP Negeri 1 Asembagus?

2. Untuk mendiskripsikan motivisi siswa di SMP Negeri 1 Asembagus ketika belajar menggunakan media chromebook?

3. Untuk mengetahui apakah ada pengaruh penggunaan media chrommebok pada siswa di SMP Negeri 1 Asembagus?

\section{Metode}

Penelitian ini merupakan penelitian survei menggunakan pendekatan kuantitatif korelasional, artinya peneliti mengumpulkan data dengan mengadakan survei lapangan kemudian dicari hubungan antar variabel. Sedangkan maksud dari penelitian survei adalah untuk mengumpulkan informasi yang menggambarkan fenomena yang menarik dengan menanyakan individu (responden) tentang: persepsi, sikap, perilaku atau nilai (moral) mereka. Dengan demikian, maka penelitian ini pada dasarnya adalah penafsiran atau penilaian terhadap laporan diri dari responden (selfreport assesement). Hal ini untuk mendeteksi seberapa jauh variasi-variasi pada suatu variabel atau lebih berhubungan dengan variasi-variasi yang terdapat dalam variabel-variabel yang lain berdasarkan koefisien korelasinya. ${ }^{5}$

Jenis penelitian ini dapat diklarifikasikan sebagai penelitian lapangan (Field Research) dengan kuantitatif. Penelitian kuantitatif adalah suatu penelitian dimana datanya dinyatakan dalam bentuk kuantitatif. Data kuantitatif merupakan data berupa angka yang bisa diperoleh dari hasil penjumlahan atau bisa juga hasil pengukuran dan analisis kuantitatif yang disebut statistik. Statistik merupakan alat analisis data yang bekerja dengan angka.Oleh karena itu, pemakaiannya selalu terlibat dalam kalkulasi numerik. ${ }^{6}$

Dalam penelitian ini terdapat berbagai metode pengumpulan data, yang mana tiap metode mempunyai ketetapan sendiri dalam mengungkap suatu variabel. Oleh karena itu

5 Husaini Usman, dan Akbar Purnomo Setiady, Metodologi penelitian sosial (Jakarta: Bumi Aksara, 2006), 5 jarang dalam suatu penelitian menggunakan metode tunggal.

Penelitian menggunakan penelitian populasi, populasi yang dipakai adalah seluruh siswa kelas VII SMP Negeri 1 Asembagus yang berjumlah 286 dan teknik yang digunakan adalah teknik samling kelas untuk menentukan sampel pada penelitian ini adalah menggunakan rumus slovin.

$$
\begin{array}{ll}
\text { Rumus Slovin: } & n=\frac{N}{N \cdot d^{2}+1} \\
& \text { dimana: } \\
& \mathrm{n}=\text { ukuran sampel } \\
& \mathrm{N}=\text { ukuran populasi } \\
\mathrm{d}=\text { galat pendugaan }
\end{array}
$$

Dalam penelitian ini menggunakan Skala data dan instrumen penelitian, skala yang digunakan adalah Skala Likent digunakan untuk mengukur pendapat sikap dan persepsi seseorang atau kelompok orang tentang fenomenal sosial jawaban dari setiap item mempunyai gradasi yang sangat positif dan bisa menggunakan checklist ataupun pilihan ganda

Kedua, instrumen penelitian adalah bagian yang rumit dari keseluruhan proses penelitian, kesalahan dibagian ini dapat dipastikan suatu penelitian akan gagal atau berubah konsep. Oleh karena itu, kerusakan instrumen penelitian pada dasarnya tidak terlepas dari peranan desain yang telah dibuat.

Dalam proses pengumpulan data ada banyak metode yang digunakan dan disesuaikan dengan jenis penelitiannya untuk memperoleh data yang valid dan akurat. Dalam penelitian ini ada beberapa metode yang dianggap tepat dan sesuai dengan permasalahan sebagai berikut: Angket (Kusioner), Observasi.

Teknik analisa data yang digunakan dalam penelitian ini adalah Analisis Statistik Deskriptif Analisis deskriptif adalah untuk mendapatkan gambaran secara umum tentang data hasil penelitian. Untuk mengklasifikasikan data deskriptif akan dikategorisasikan menjadi empat kelompok yaitu sangat tinggi, tinggi, rendah dan sangat rendah. Kedua analisis korelasi product moment merupakan salah satu teknik mencari

6 Mundir, Statistike Pendidikan, (Yogyakarta: Pustaka Belajar, 2014), 2. 
hubungan antara dua variabel dengan cara memperhatikan momen-moment kedua variabel tesebut. Dalam penelitian ini menggunakan korelasi product moment karena variabelnya berupa interval dan untuk menyatakan ada atau tidaknya hubungan antara variabel $\mathrm{X}$ dan variabel Y. ${ }^{7}$

\section{KERANGKA KONSEPTUAL}

\section{Media Pembelajaran Chrome Book}

Media pembelajaran merupakan alat bantu yang berfungsi untuk menjelaskan sebagian dari keseluruhan program pembelajaran yang sulitdijelaskan secara verbal. secara umum media pembelajaran dibagi menjadi 4 yaitu Audio, visual, Audio Visual dan Multimedia. ${ }^{8}$

Chromebook termasuk dalam kategori multimedia karena mampu melibatkan berbagai indera seperi Audio, Visual, dan Kinetik. Chromebook merupakan hasil perkembangan dari komputer dan menggunakan google chrome sebagai sistem operasinya. Oleh karena itu, chromebook merupakan media pembelajaran yang termasuk dalam kategori multimedia dan merupakan perkembangan dari komputer dan laptop.

\section{Motivasi Belajar}

Kata Motif diartikan sebagai upaya yang mendorong seseorang melakukan sesuatu. Menurut Mc. Donal, motivasi adalah perubahan energi dalam diri seseorang yang ditandai dengan munculnya"feeling"dan didahului dengan tanggapan terhadap adanya tujuan. ${ }^{9}$ Maka, motivasi menurut peneliti ialah suatu dorongan agar seseorang melakukan sesuatu. Motivasi bisa berupa dukungan, daya penggerak dalam diri seseorang untuk melakukan kegiatan belajar dan mengarah untuk mencapai suatu tujuan.

\section{HASIL DAN PEMBAHASAN}

Dalam penyajian data yang hubungannya dengan masalah penelitian, digunakan metode angket yang disebarluaskan kepada sejumlah responden dengan sebuah tujuan untuk mengetahui sejauh mana pengaruh penggunaan media pembelajaran chromebook terhadap motivasi belajar siswakelas VII di SMP Negeri 1

\footnotetext{
7 Subana, Statistik Penelitian (Bandung: CV6 Pustaka Setia, 2000), 141

8 Wina Sanjaya, Perencanaan dan Desaign Sistem Pembelajaran, (Jakarta: Kencana Prenada Group, 2012), 211.
}

Asembagus Situbondo Tahun Pelajaran 20182019.

Adapun langkah-langkah yang digunakan dalam penelitian ini meliputi angket, dokumentasi, interview, dan observasi. Langkah ini mempermudahkan memperoleh data hasil penelitian.

Untuk memperoleh data yang dimaksud, digunakan penyebaran angket kepada responden sebanyak sampel yang akan ditentukan dalam lembar berikutnya. Dokumentasi digunakan untuk memperoleh data tentang keberadaan chromebook dan bukti serah terima. Interview dan observasi dilaksanakan untuk melihat dan memperoleh data tentang bagaimana penggunaan chromebook bagi siswa.Sedangkan teknik yang digunakan dalam menentukan responden sebagai sampel dari populasi yang ada adalah teknik sampling kelas atau cluster. Dari 286 siswa SMP Negeri 1 Asembagus diambil sampel 61 siswa, yakni kelas VII B dan VII C. Responden yang diambil dari kelas VII B ialah 32 siswa dan 29 siswa kelas VII C.

\section{Penggunaan Media Chromebook Pada Siswa di SMP Negeri 1 Asembagus}

Pada bab ini akan mendiskripsikan penggunaan media chromebook pada siswa di SMP Negeri 1 Asembagus data yang dianalisis adalah hasil angket variabel $\mathrm{X}$ (Penggunaan Chrommebok bagi siswa) analisis data yang digunakan ialah analisis statistik diskriptif dan analisis product moment analisis data digunakan untuk mengukur persepsi respondent terhadap penggunaan media chrommbook.

Hasil penelitian tentang penggunaan media chromebook bagi siswa mencapai skor 1951 simpangan baku (Standar deviasi) yaitu 2.27 dengan skor terendah 26, skore tertinggi 38 dan mean 31,98. Penggunaan chromebook bagi siswa termasuk kategori bagus. Berikut ini distribusi frekuensi untuk kelompok tersebut.

Tabel

Distribusi penggunaan media chromebook

9 Sardiman, Interaksi dan Motivasi Belajar Mengajar, (Jakarta: Rajawali Press, 2012), 20. 


\begin{tabular}{|l|l|l|l|l|}
\hline $\begin{array}{l}\text { N } \\
\mathbf{o}\end{array}$ & Skor X & Kriteria & $\begin{array}{l}\text { Frek } \\
\text { uensi }\end{array}$ & $\begin{array}{l}\text { Presenta } \\
\text { se }\end{array}$ \\
\hline 1 & $\mathrm{X}>34.70$ & $\begin{array}{l}\text { Sangat } \\
\text { baik }\end{array}$ & 12 & $19,67 \%$ \\
\hline 2 & $\begin{array}{l}34,70>\mathrm{X} \\
\geq 31,98\end{array}$ & Baik & 21 & $34,43 \%$ \\
\hline 3 & $\begin{array}{l}31,98>\mathrm{X} \\
\geq 29,27\end{array}$ & Cukup & 19 & $31,15 \%$ \\
\hline 4 & $\mathrm{X}<29,27$ & Kurang & 9 & $14,75 \%$ \\
\hline \multicolumn{5}{|l|}{ Jumlah } \\
\hline
\end{tabular}

Dari tabel diatas dijelaskan bahwa terhadapat 12 siswa dengan kriteria sangat baik, 21 siswa pada kriteria baik, 19 siswa masuk kriteria cukup dan ada 9 siswa masuk kriteria kurang.

Untuk memperjelas hasil, berikut disajikan skor penggunaan media pembelajaran dengan grafik sebagai berikut!

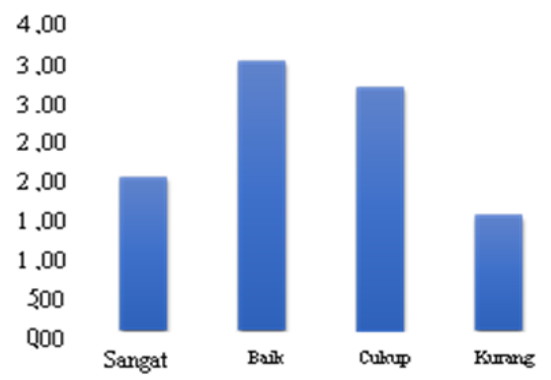

Grafik hasil angket variabel $\mathrm{X}$

Dari hasil di atas dapat disimpulkan bahwa penggunaan chromebook bagi siswa termasuk kategori baik. Penggunaan media pembelajaran chromebook termasuk kategori baik karena sarana dan prasarana yang dipakai di SMP Negeri 1 Asembagus telah memenuhi syarat untuk digunakan ketika pembelajaran bagi siswa.

Chromebook termasuk jenis media pembelajaran baru. Oleh karena itu siswa sangat antusias ketika memakai chromebook ketika pembelajaran, karena chromebook merupakan media baru yang unik. Dalam teori, media pembelajaran merupakan perantara yang dipakai guru untuk menyampaikan pesan kepada murid. Jika hal tersebut dikaitkan dalam pembelajaran, maka pembelajaran akan lebih efektif apabila mengngunakan media yang baik. Teori tersebut diterima di SMP Negeri 1 Asembagus, karena sarana dan prasarana terutama media yang digunakan untuk pembelajaran dikategorikan modern dan mengikuti perkembangan yang ada.
Hal ini berdasarkan observasi yang dilakukan ketika penelitian bahwa sarana dan prasarana di SMP Negeri 1 Asembagus sudah memenuhi standar sarana prasarana.

Di SMP negeri 1 Asembagus media chromebook merupakan media pembelajaran model baru. Chromebook diberikan oleh pemerintah sebanyak 300 unit dan hanya digunakan untuk kelas VII karena merupakan jenjang awal. Chromebook baru digunakan awal semester 2, dan untuk saat ini siswa masih jarang yang mahir dalam menggunakan media chromebook dikarenakan chromebook merupakan media baru dan jarang sekali sekolah yang menggunakannya. Dalam menggunakan chromebook, para guru diwajibkan mengikuti pelatihan penggunaan chromebook selama 4 hari. Sebelum para guru mengikuti pelatihan, ada 4 guru yang ikut pelatihan penggunaaan chromebook yang dibimbing langsung oleh pihak google.

Pelatihan guru di SMP Negeri 1 Asembagus sendiri, dibimbing oleh guru yang mengikuti pelatihan bersama pihak google. Pelatihan tersebut dilakukan agar ketika menggunakan chromebook, para guru tidak kebingungan ketika salah satu siswa ada yang belum faham saat menggunakan chromebook, karena penggunaan chromebook dilakukan secara online. Sarana prasarana yang dipakai dalam pembelajaran mengikuti perkembangan zaman yang bersifat modern seperti Smartboard (pengganti papan dan LCD), Chromebook, penggunaan CBT ketika ujian harian, ulangan semester dan Ujian Nasional atau lainnya.

Chromebook yaitu media yang serupa dengan laptop tetapi penggunaannya secara online. Chromebook merupakan media yang dipakai bagi siswa kelas VII di SMP Negeri 1 Asembagus hal ini berdasarkan dokumen yang didapat yakni berupa nota serah terima chromebook kepada sekolah. Melalui chromebook, siswa mengumpulkan tugas bisa langsung kirim lewat email ke guru.

Motivasi Belajar Siswa SMP Negeri 1 Asembagus 
Pada sub ini akan mendeskripsikan tentang motivasi belajar siswa ketika menggunakan media pembelajaran chromebook. Data yang dianalisis merupakan hasil angket variabel Y (motivasi belajar siswa) analisis data yang digunakan adalah analisis statistik deskriptif dan analisis product moment. Analisis data yang dilakukan untuk mengukur seberapa tinggi motivasi belajar siswa ketika menggunakan media pembelajaran chromebook. Hasil penelitian tentang motivasi belajar siswa pada variabel Y mencapai skor 1869. Simpangan buku (Standar diviasi) yakni 3.20 dengan skor terandah 24 , skor tertinggi 39 dan mean 30.64. Motivasi belajar siswa termasuk kategori cukup. Berikut ini distribusi frekuensi untuk kelompok tersebut.

Tabel

Distirubusi motivasi belajar

\begin{tabular}{|l|l|l|l|l|}
\hline No & Skor Y & Kriteria & $\begin{array}{l}\text { Freku } \\
\text { ensi }\end{array}$ & Presentase \\
\hline 1 & $\begin{array}{l}\mathrm{X}> \\
33,84\end{array}$ & $\begin{array}{l}\text { Sangat } \\
\text { baik }\end{array}$ & 11 & $18,03 \%$ \\
\hline 2 & $\begin{array}{l}33,84 \\
>\mathrm{X} \\
\geq 30,64\end{array}$ & Baik & 16 & $26,23 \%$ \\
\hline 3 & $\begin{array}{l}30,64 \\
>\mathrm{X} \\
27,44\end{array}$ \\
4 & $\begin{array}{l}\mathrm{X}< \\
27,44\end{array}$ & Kukup & 23 & $37,70 \%$ \\
\hline Jumlah & 11 & $14,75 \%$ \\
\hline
\end{tabular}

Dari tabel di atas dijelaskan bahwa terhadapat 11 siswa dengan kriteria sangat baik, 16 siswa pada kriteria baik, 23 siswa masuk kriteria cukup dan ada 11 siswa masuk kriteria kurang. Untuk memperjelas hasil, berikut disajikan skor motivasi belajar siswa dalam bentuk grafik.

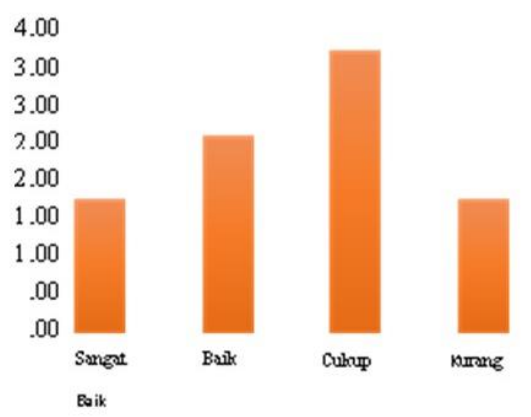

Dari hasil dari grafik diatas dapat disimpulkan bahwa motivasi siswa ketika belajar menggunakan media chromebook kategori cukup.
Sedangkan hasil angket yang didapat dari variabel $\mathrm{Y}$ berupa tabel dan grafik. Hasil penelitian tentang motivasi belajar siswa, mencapai skor 1869 dengan simpangan baku (Standar Deviasi) 3,20, skor terendah 24, skor tertinggi 39, dan mean 30,64. Motivasi belajar siswa termasuk kategori cukup. Setelah dianalisis, terdapat 11 siswa dengan kriteria sangat baik. Sedangkan 16 siswa berada pada kriteria baik. Pada kriteria cukup, terdiri dari 23 siswa. Lantas, ada 11 siswa berada pada kriteria kurang.

Motivasi belajar siswa kelas VII di SMP Negeri 1 Asembagus termasuk kategori kurang, karena sebagian dari mereka ada yang masih belum paham ketika menggunakan chromebook. Disamping penggunaanya secara online chromebook termasuk media baru dan pemakaiannya belum maksimal hanya beberapa siswa yang baru bisa menggunakan media tersebut dengan baik.

Chromebook yaitu media yang serupa dengan laptop tetapi penggunaannya secara online. Chromebook merupakan media yang dipakai bagi siswa kelas VII di SMP Negeri 1 Asembagus hal ini berdasarkan dokumen yang didapat yakni berupa nota serah terima chromebook kepada sekolah. Dengan cbromebook, siswa mengumpulkan tugas bisa langsung kirim lewat email ke guru.

Hal itu serupa dengan yang dikemukakan oleh Nana Sudjana bahwa media pembelajaran dapat mempertinggi proses belajar siswa dalam pembelajaran yang pada akhirnya dapat mempertinggi hasil belajar yang dicapainya. Pembelajaran dengan menggunakan media pembelajaran akan lebih menarik perhatian siswa sehingga dapat menumbuhkan motivasi belajar.

Motivasi ada 2 macam, salah satunya motivasi ekstrinsik yaitu motivasi yang disebabkan oleh faktor-faktor dari situasi belajar. Media pembelajaran merupakan faktor dari situasi belajar yang bisa menyebabkan tingginya motivasi belajar siswa. Salah satu cara memotivasi siswa ialah dengan belajar melalui model, melakukan interaksi, wisata alam, dan menyajikan materi dengan teknik yang baru dan didukung oleh media yang belum pernah dikenal oleh siswa sebelumnya 
Hal itu serupa dengan yang dikemukakan oleh Nana Sudjana bahwa media pembelajaran dapat mempertinggi proses belajar siswa dalam pembelajaran yang pada akhirnya dapat mempertinggi hasil belajar yang dicapainya. Pembelajaran dengan menggunakan media pembelajaran akan lebih menarik perhatian siswa sehingga dapat menumbuhkan motivasi belajar. ${ }^{10}$

\section{Pengaruh Penggunaan Media Chromebook terhadap Motivasi Belajar Siswa}

Hasil angket yang didapat pada variabel $\mathrm{X}$ berupa tabel dan grafik. Hasil penelitian tentang penggunaan media pembelajaran chromebook bagi siswa mencapai skor 1951 dengan simpangan baku (Standar Deviasi) 2,27, skor terendah 26, skor tertinggi 38, dan mean 31,98. Penggunaan media pembelajaran chromebook bagi siswa termasuk kategori bagus.

Setelah dianalisis, terdapat 12 siswa dengan kriteria sangat baik. Sedangkan 21 siswa berada pada kriteria baik. Pada kriteria cukup, terdiri dari 19 siswa. Lantas, ada 9 siswa berada pada kriteria kurang.

Sedangkan hasil angket yang didapat dari variabel $\mathrm{Y}$ berupa tabel dan grafik. Hasil penelitian tentang motivasi belajar siswa, mencapai skor 1869 dengan simpangan baku (Standar Deviasi) 3,20, skor terendah 24, skor tertinggi 39, dan mean 30,64. Motivasi belajar siswa termasuk kategori cukup. Setelah dianalisis, terdapat 11 siswa dengan kriteria sangat baik. Sedangkan 16 siswa berada pada kriteria baik. Pada kriteria cukup, terdiri dari 23 siswa. Lantas, ada 11 siswa berada pada kriteria kurang.

Koefisien korelasi adalah 0,543 dengan signifikasi 0,000. Karena signifikasi berada pada $<0,05$, maka Ho ditolak dan Ha diterima. Artinya ada pengaruh penggunaan media pembelajaran chromebook terhadap motivasi belajar siswa.

Koefisien korelasi hasil analisis korelasi Product Moment tersebut perlu dibandingkan dengan $r_{\text {tabe }}$

a. Jika $\mathrm{r}_{\text {hitung }}>\mathrm{r}_{\text {tabel, }}$ maka Ho ditolak

\footnotetext{
${ }^{10}$ Mardhiyah, "Strategi Guru Dalam Meningkatkan Motivasi
} Belajar Peserta Didik Pada Mata Pelajaran Al-Qur'an dan b. Jika $\mathrm{r}_{\text {hitung }}<\mathrm{r}_{\text {tabel, }}$, maka Ho diterima

Dengan taraf signifikan 5\%, maka dapat diperoleh $\mathrm{r}$ tabel 0,254.Jadi $\mathrm{r}$ hitung $>\mathrm{r}_{\text {tabel }} 0,543>$ 0,254 maka Ho ditolak dan Ha diterima.Artinya ada pengaruh penggunaan media pembelajaran chromebook terhadap motivasi belajar siswa.

Berdasarkan hasil koefisien korelasi tersebut bersifat positif, artinya ketika guru menggunakan media pembelajaran jenis baru dan berteknologi canggih bisa meningkatkan motivasi belajar siswa, namun dengan menyeimbangkan tingkat kemampuan siswa dan penggunaannya harus secara optimal.

Setelah diketahui jumlah veriabel $\mathrm{X}$ (Media Pembelajaran Chromebook) dan variabel Y (Motivasi Belajar) data dianalisis menggunakan SPSS. Pada perhitungan ini digunakan analisis korelasi product moment. Perhitungan menggunakan SPSS dengan taraf signifikan 0,000 $<0,05$ dan $\mathrm{r}_{\text {hitung }}>\mathrm{r}_{\text {tabel }} 0,543>0,254$ maka Ho ditolak maka ada pengaruh penggunaan media pembelajaran chromebook terhadap motivasi belajar siswa kelas VII di SMP Negeri 1 Asembagus.

\section{SIMPULAN}

Berdasarkan hasil penelitian yang telah dilakukan dan pembahasan yang telah dipaparkan pada bab sebelumnya, maka kesimpulan yang diperoleh dalam penelitian ini adalah Ho ditolak dan $\mathrm{Ha}$ diterima. Artinya ada hubungan antara pengaruh penggunaan media pembelajaran chromebook terhadap motivasi siswa kelas VII di SMP Negeri 1 Asembagus.

Berdasarkan analisis yang diperoleh, maka dapat disimpulkan bahwa: 1) Penggunaan media pembelajaran chromebook bagi siswa tergolong kategori baik. 2) Motivasi belajar siswa ketika menggunakan media pembelajaran tergolong kategori cukup. 3) Ada pengaruh penggunaan media pembelajaran chromebook terhadap motivasi belajar siswa kelas VII di SMP Negeri 1 Asembagus. Hal tersebut dapat dilihat dari perhitungan pada tabel correlation pada SPSS dimana koefisien korelasi adalah 0,543 dengan signifikasi 0,000. Karena signifikasi $<0,05$, maka Ho ditolak berarti $\mathrm{Ha}$ diterima dan $\mathrm{r}$ hitung $>\mathrm{r}$

Hadits", Fikrah: Journal Of Islamic Education 2, No. 1, (2018): $1-12$. 
tabel0,543 $>0,254$. Kesimpulannya terdapat pengaruh yang sangat kuat penggunaan media pembelajaran chromebook terhadap motivasi siswa kelas VII di SMP Negeri 1 Asembagus.

\section{DAFTAR RUJUKAN}

U. Saefullah. Psikologi Perkembangan dan Pendidikan. Bandung: CV Pustaka Setia, 2012.

Undang Undang RI Nomor 20 Tahun 2003 Tentang SISDIKNAS dan Peraturan RI Tahun 2013 Tentang Dasar, Fungsi, dan Tujuan, Bandung: Citra Umbara, 2014.

Sutrisno. Pengantar Pembelajaran Inovatif Berbasis Teknologi Informasi dan Komunikasi (TIK). Jakarta: Gaung Persada, 2011.

Yudi, Munadi. Media Pembelajaran Sebagai Pendekatan Beru. Jakarta: GP Press Group, 2013.

Usman, Husaini dan Akbar Purnomo Setiady, Metodologi penelitian sosial. Jakarta: Bumi Aksara, 2006.

Mundir, Statistik Pendidikan. Yogyakarta: Pustaka Belajar, 2014.

Subana, Statistik Penelitian. Bandung: CV 6 Pustaka Setia, 2000.

Sanjaya, Wina. Perencanaan dan Desaign Sistem Pembelajaran. Jakarta: Kencana Prenada Group, 2012.

Sardiman. Interaksi dan Motivasi Belajar Mengajar. Jakarta: Rajawali Press, 2012.

Mardhiyah. "Strategi Guru Dalam Meningkatkan Motivasi Belajar Peserta Didik Pada Mata Pelajaran Al-Qur'an dan Hadits", Fikrah: Journal Of Islamic Education 2, No. 1, (2018): 1-12. 